\title{
The Impact of Employee Empowerment on the Success of Organizational Change: A Study in Privatized Enterprises in Jordan
}

\author{
Batool Bader Al-Asoufi \\ Department of Public Administration, School of Business \\ University of Jordan \\ E-mail: batoolb_88@yahoo.com
}

\begin{abstract}
Abdel Hakim Oqlah Akhorshaideh (Corresponding author)
Assistant Professor, Department of Public Administration, School of Business

University of Jordan

E-mail: a.hakim@ju.edu.jo
\end{abstract}

Received: December 21, 2016 Accepted: March 15, 2017 Published: April 05, 2017

doi:10.5296/jpag.v7i1.10849 URL: http://dx.doi.org/10.5296/jpag.v7i1. 10849

\begin{abstract}
The purpose of this study is to examining the Impact of employee empowerment on the success of organizational change, within the privatized enterprises in Jordan, also the study examined four significant factors which influence the success the employee empowerment process those are (Talent Management, Leadership Styles, Employee Training, Rewards) and their impacts on the success of organizational change. A total of (143) questionnaires has been distributed, it was returned constituting approximately (99\%) from those distributed to targeted samples in each of Electricity Distribution Company and Jordan Phosphate Mines Company.

The data were tested using simple and multiple regression tests to examine the study hypotheses. The findings showed that there is a significant impact of employee empowerment on the success of organizational change, also there is significant impact of employee empowerment factors (Talent Management, Leadership Styles, Employee Training, Rewards) on the success of organizational change. Also, the results showed the importance of providing sufficient information about the nature of change and its positive impact to raising the level
\end{abstract}


of readiness for it and reducing the resistance.

Keywords: Empowerment, Organizational change, Enterprises, Jordan

\section{Introduction}

Due to the fast-paced nature of the business environment, empowering employees for higher levels of performance, commitment and involvement is a critical point that must be addressed. Modern companies that motivate and support their employees will be more likely to achieve maximum effectiveness throughout the organization as a whole, and will enable them to be more responsive in the rapidly changing business environment.

The empowerment is a new topic that is characterized by its importance in the business fast-tracked environment, which demands intelligence and rapidity in the decision-making, both from the manager and employee. Not surprisingly, empowerment and its organizational effects have received considerable attention over the last decade from both scholars and practitioners (Voegtlin et. el, 2015). Empowerment has a special significance due to the connection and consistency it has with several important matters and issues, such as the decentralization, motivation, teamwork, and the participatory decision making, and other topics that impact the organization's success and competitive strength.

Talent Management, Leadership style, Employee Training and rewards are the factors that has a role in the success of empowerment, as it includes the employees and their interests, the managers and their styles of leadership, and achieving a partnership between them to reach the desired results, thus ensuring that this strategy is a tool for achieving the success of the Organization and increasing its efficiency and productivity. Each of (Blanchard et al, 1999; Randolph 1995, 2000) considered empowerment as a collection of practices that combine information sharing, a delegation of authority, and increased employee autonomy. Empowerment as described by Bowen and Lawler, (1992) "a means to enable employees to make a decision". While (Pastor, 1996) described as "a personal phenomenon where individuals take responsibility for their own actions".

Organizations today exist in an environment that is not constant, there are large dominant organizations, and there are small organizations that are trying to prove themselves and seeking to grow and expand, and some organizations that have failed to compete and had to leave the market. Therefore, any change in the external environment regardless of its size affects the path of organizations and has an impact on its inside environment. Therefore, it is imperative for the organization and its leaders to have sufficient awareness and be familiar with all the sequences of the environment to deal with any emergency intelligently and wisely. Al-Haddad and kontour, (2015), "Many approaches and methods have been suggested to manage change, yet organizations undergoing change, vary significantly in their structure, systems, strategies and human resources".

The idea of privatization began to emerge in Jordan in (1985), and began work on its application in late 1996, in order to keep pace with technological developments and to 
strengthen the partnership with the private sector as part of the Jordanian economy, in addition to upgrading performance piece for the economy and get the biggest returns(Alsherqatli,2010).

Ali (2007), argued that the privatization is a policy which of turning the leadership of economic activity over to the private sector by ownership or by management within the rules and laws of the state. According to Alsherqatli (2010) the privatization program in Jordan is of the most successful privatization programs in the region, -the testimony of the most important international organizations (World Bank, the US Agency for International Development, the group of European and others) and in the world, the revenues of privatization process resulting from the sale proceeds reached (1723.2) million (until 31-12-2008), and the total amount that has been spent of the net proceeds to privatize companies amount (1719.1) million, which helped reduce the debt of Jordan (Ministry of Finance, 2009).

This study is characterized by the innovation of its subject, through its focus on the concept of empowerment, and how to support the employees through organizational change process, in addition to discovering talented leaders and employees in a right way to get the backing and support during the process of change, taking into consideration that the current environment of the organizations is rapidly changing, making this study consistent with requirements the current environment.

\section{Literature Review}

\subsection{Employee Empowerment}

Many institutions and companies show explicit attention to its human resources in the light of the rapid changes and the enormous challenges it faces, and to pursuit the organization competitive advantages. That resulted in expressing the interest in the individuals working in the organizations through implementing the empowerment approach as it has a clear impact in creating trust between the management and the employees, adding to that expanding the responsibilities, and solving problems smoothly through delegation of authorities, as well as motivating individuals to participate in the decision-making moving towards applying the concept of the decentralization effectively. Melhem, (2009) explained that the concept of empowerment began to emerge after the nineties of last century, it did not emerge suddenly but rather was a cumulative and evolutionary result throughout more than hundred years of evolution in various administrative concepts.

Employee empowerment as defined by Langbein (2000); Dainty et al., (2002); Arneson and Ekberg, (2006) refers to "The delegation of power and responsibility from higher levels in the organizational hierarchy to lower level employees, especially the power to make decisions". Moreover, it can be defined as "To enhance the effectiveness and performance of individuals and work units". Additionally, (Ettorre, 1997) defined Employees' Empowerment as "employees having self-directed decision-making capabilities, and acting as partners in the business, with the focus on lower administrative levels, Moreover, empowerment does not only mean the delegation of employees to have decision-making powers, but it also means 
setting goals and allowing employees to participate". Hence, the common factor between all the definitions mentioned above is the emphasizing of the importance of employee's participation in decision-making and giving them powers and adequate information in order to increase their motivation and encourage them to execute their tasks well.Based on the previous definitions, and according to the researchers ${ }^{\text {ee }}$ opinion, the empowerment of employees can be defined as "The process that the organization management implement benefiting from the ideas, energies, and knowledge of its member employees. Also train, motivate, and encourage the employees to use their creativity in work, and involving them in the decision-making process, in order to achieve the goals of the organization, and raise its efficiency in the competitive environment in proportion to its technological, cultural and environmental capacity". According to Raub and Robert, (2010) "empowerment is associated with job satisfaction, managerial effectiveness (Spreitzer , 1997), creativity, and team performance (Kirkman and Rosen, 1997 ) and negatively related to strain (Spreitzer, 1997) ".

However Al-Haddad and kontour, (2015) stated that the application of the empowerment process on a wide range within the organization will lead to success in the long-term run, moreover, it has a direct link and impact on the performance level of the employees, and their feel of fulfillment. Therefore, the empowerment creates a sense of commitment and loyalty to the employees of the organization, leading to a more approachable and flexible organization. As the organization has to develop itself constantly to keep up with the changes of the fast-tracked business environment, the organization that works on its employees empowerment strategy will find them more willing to accept and adapt to changes, this will also mitigate the fear of the organization from its employees resistance to change, and help them in accepting the participation of any initiative carried out, the change in the organization cannot happen if the employee is not aware of the importance of change.

\subsection{The Factors That Influencing the Success of Empowerment}

There are many business organizations trying hard to consolidate a culture of empowerment among its employees and managers as a managerial approach, and in a manner that is flexible and simple to ensure its success. The empowerment strategy is often successful, because of its positive returns whether on the organization or its personnel, but it can be said that one of the positive factors of implementing the process has the greatest impact on the others. Therefore, there are no negative results for the empowerment and benefit will always be present.

The factors that represent the degree of success of the empowerment are:

\subsubsection{Talent Management}

According to Ingham,(2006) "the term „Talent Management" came to appear synonymous with human capital management, implying that companies are strategic and deliberate in their efforts to source, attract, select, develop, promote and move employees through the organization". The secret behind the success of organizations within the competitive business environment is having employees that own skills, capabilities, and abilities that raise the overall capabilities of the organization and enhance its performance, and move towards 
quality, innovation, and customer satisfaction. Additionally, Nilsson and Ellstro"m, (2012) said "Generally, the notion of talent management appears to be closely related to concepts that include human resource planning, strategic human resource management, and employability" (as cited in Brown and Hesketh, 2004; Collings and Mellahi, 2009; Lewis and Heckman, 2006).

\subsubsection{Leadership Style}

When an organization adopts the empowerment strategy and approach, there must be some changes taking place in its environment to facilitate the implementation of this strategy. The change in the management and leadership patterns is one of the most important success factors of the empowerment, avoiding the conventional role from the managers side in dealing with the employees and creating trust within the relation, and helping the employees in learning and developing leads to the sense of individual's responsibility and loyalty towards the organization. (Arnold and colleagues, 2000), they describe empowering leadership behaviors (ELBs) as behaviors that facilitate employee performance in empowered work environments by enabling and encouraging workers in their work roles. The specific behaviors include leading by example, coaching, informing, showing concern, and participative decision-making. empowering leaders, motivates them and sharing knowledge between each other's make a great form of collaborate and helping others, therefore, the empowerment is not an easy process, as it needs joining the efforts and roles between the management and employees. Furthermore, this process is complex and there is an overlap in its procedures, it is impossible to succeed in empowerment within an unhealthy and not suitable environment for production and creativity.

\subsubsection{Employee Training}

After choosing the new employees to work in an organization, the line manager starts guiding the employees, this process is called orientation and is defined according to Dessler, (2015) as "the procedure of providing new employees with basic background information about the firm". The purpose of this procedure is helping the new employee to feel as a part of the team and is welcomed in the organization. Also, mentoring and guiding him to the basics of the work, and get introduced to the policies and strategies of the organization, laws, and regulations of incentives, rewards, and vacations. Also, get introduced to the values and culture of the organization and its previous achievements, and future plans. Dessler, (2015), defines training as "the process of teaching new or current employees the basic skills they need to perform their jobs". It should be noted that training programs are not necessarily only for new employees, each employee needs to get training to improve his or her performance and enhance weakness areas. That would be evaluated by the manager through the daily and routinely continuous guidance, also through the annual appraisal that addresses the strengths and weaknesses of the employee's performance. Following to this, weak performance will be improved through training programs that will enhance the performance to get the best outcomes, happening in parallel with showing appreciation of good performance by the manager, which would motivate employees for more productivity to get promoted to a higher position. 


\subsubsection{Rewards}

Al-Otaibi, (2004) suggests that ensuring a successful empowerment, the higher level management has to give an adequate attention to the incentives, and rewards. Moreover, linking them to the objectives of the organization and the performance of its employees. The higher level management in the organization should strive to build up and develop its relationship with the staff, and focus on the financial and non-financial support in order to motivate them to boost their productivity and achieve the highest level of performance.

the management seizes this opportunity and pursues the approach of empowerment in achieving the best results, meaning that the employee who outperforms gets bigger incentives, and this leads to creating a spirit of competition among employees, and their quest to motivation, efficiency and to hold bigger responsibility.

\subsection{The success of Organizational Change}

When the organization starts an initiative to change, the aim is enhancing the performance level. Therefore, it should be taken into consideration the employee's willingness to accept this step, and introduce them to its importance, to enable it to succeed. The response of workers is a key player in the success or failure of this initiative. According to (Jones, 2013) he defines organizational change as the process by which organizations move from their present state to some desired future state to increase their effectiveness.

Organizations need programs and curricula integrated to cope with change, to benefit from positive effects, and to avoid the drawbacks. Unfortunately, in spite of the huge development that occurs, and prosperity in the business environment, there are still lots of organizations which have failed in pursuing change and applying this initiative on their employees. According to studies that contributed to enriching this subject such as (Balogun and Hope Hailey, 2004; Beer and Nohria, 2000; Grover, 1999), "the organizations that have been successful in their approach to change do not exceed $30 \%$ ". This percentage refers to the importance of research, and finds factors that help to ensure the success of change in organizations, and draw the attention of academics to the figure to make enough studies to come up with recommendations for future benefit. The reasons for the change process failure are several and complex, but there are key factors that summarized by (Balogun and Hope Hailey, 2004; Beer and Nohria, 2000; Grover, 1999) these included:

1. The failure in developing accurate and realistic plans for the change process.

2. Weakness of the administration's performance and its inability to control the employee's performance and giving them responsibilities.

3. Based on the previous point, where there is a weakness in the process of communication between management and employees, that leads to lack of trust in the relation.

4. The culture of the organization environment that does not allow the change to take place smoothly.

5. The influence of external forces and the difficulty of controlling and predicting its 
dimensions, such as the political, economic, legislative and technological environment.

The change is intended mainly to move the current reality to the reality of a future, to achieve the goals, improve the service providing performance, introducing new resources to the organization, in addition to the allowing managers to follow the objective management approach, and get rid of the traditional methods of administration, thus ensuring the achievement of the organization's growth.

There are three steps of change process, identified by lewin's, (1951):

\begin{tabular}{|c|c|c|}
\hline $\begin{array}{l}\text { 1. Unfreeze the } \\
\text { organization from its } \\
\text { present state. }\end{array}$ & $\begin{array}{l}\text { 2. Make the desired } \\
\text { type of change. }\end{array}$ & $\begin{array}{l}\text { 3. Refreeze the } \\
\text { organization in a } \\
\text { new, desired state. }\end{array}$ \\
\hline
\end{tabular}

Figure 1: Steps of Change Process

Source: lewin's, (1951)

The first step begins by unfreezing the current situation of the organization, and working on diagnosing it, then planning the change program, taking into account developing programs to convince employees to change, ensure their readiness, and reducing their resistance, followed by determining the change targets and appropriate strategies of implementation.

After the completion of this stage, and getting the initial acceptance of the employees, the organization begins the implementation of change. It is advisable that the senior management does this step to ensure getting the backing and support, and to deal with any attempts of resistance positively, and in a conscious manner.

After the completion of implementing the change, the organization begin the coexistence and adaptation to the new situation, interrupted occasionally by monitoring and evaluating the change plan, and follow up on any deviations from the track.

Therefore it could be conclude that there are many employees that are open and welcoming to changes, they collaborate with the senior management to implement it as they consider these changes an opportunity to get a better career path, and solve the problems at work, in contrast. According to (Weiner,2009), organizational readiness for change has been defined as the "organizational members ${ }^{\text {ee }}$ change commitment and self-efficacy to implement organizational change". There are some employees who are against and refuse the change for several reasons, such as:

1. The employee may see the change as a threat to his future career, and therefore he will feel fear and insecurity.

2. Some employees like the work routine and refuse any attempt to develop or expand their work.

3. If the employees and the senior management do not share the same views and goals, the change process will be faced with employee's rejection 


\section{Macrothink}

Journal of Public Administration and Governance

ISSN 2161-7104

2017, Vol. 7, No. 1

4. The nonrealistic process of change and the lack of a sense of their importance and value.

So, individuals play a significant role in the success of the change process if the employees are ready for the change, and the management reaches out to them and did not strive towards forcing or coercing them to change, the results will be better. Adding to this benefiting from the employee's ideas and creativity, and investing in the organization resources to achieve the organization's interest as a whole, instead of bringing in experts and advisers from outside the organization to propose new ideas to improve the level of work, which is an extra burden on the budget because of its high cost.

\section{Research Model and Hypotheses}

The main objective of this study is to investigate four significant factors which influence the success the employee empowerment process those are (Talent Management, Leadership Styles, Employee Training, Rewards) and their impacts on the success of organizational change. The independent variable represented by employee empowerment which include central factors such as (Talent management, leadership style, employee training and rewarding) while the dependent one represented by success of organizational change. Research model is represented in figure 1.

\section{Employee Empowerment}

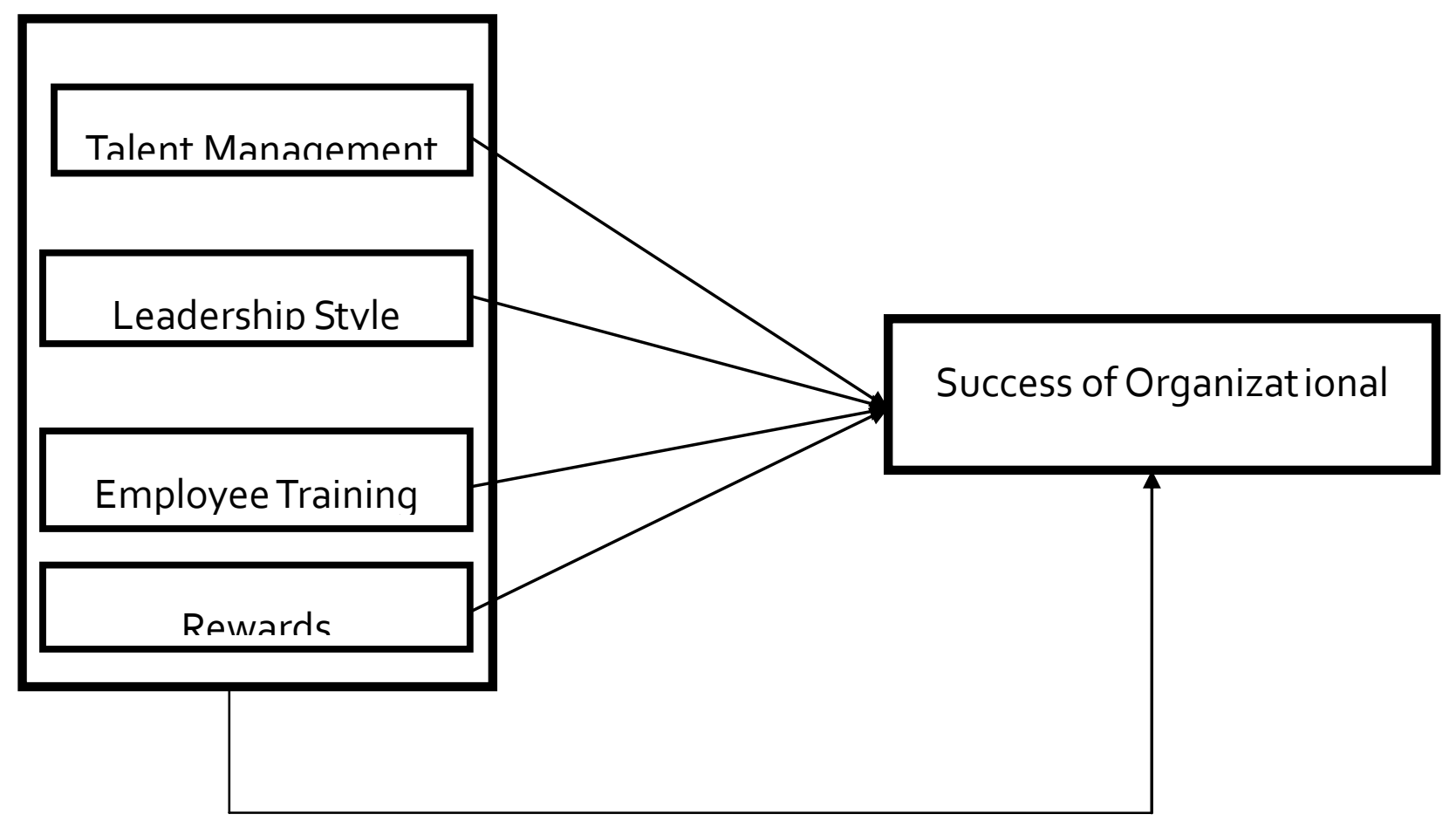

Figure 1: Developed by researchers based on the literature review

To achieve the study objectives, the following main hypotheses was formulated:

H1: Employee empowerment has significant impact on success of organizational change 


\section{MlMacrothink}

The other Sub hypotheses are:

H1-1: Talent management has significant impact on success of organizational change.

H1-2: leadership style has significant impact on success of organizational change.

H1-3: Employee training has significant impact on success of organizational change.

H1-4: Rewards has significant impact on success of organizational change.

\section{Research Methodology}

In order to evaluate how the factors of employee empowerment (Talent management, leadership style, Employee training and Rewards) effect on success of organizational change, this study adopted quantitative approach which required a preparation of a questionnaire as a main tool to gather the needed data and to discuss the information from the collected data.

The population of the study is a tow of privatized enterprises in Jordan: Electricity Distribution Company and Jordan Phosphate Mines Company. 143 questionnaire were distributed to the employees who are working in the low management position, and leaders who are working in the middle management position. These two organization was conducted because they are the only organizations that get approval to researcher to distribute study questionnaire to their employees. In order to examine the hypotheses associated with this research, the collected data will help examine the relationship between the variables of study. The statistical analysis will be conducted using Statistical Package for Social Science (SPSS), version 20, using simple and multiple regression test to obtain the results that will lead to the acceptance or rejection of the hypotheses, also will discussed and presented the recommendations in this regard

\section{Data Analysis and Results}

In order to investigate the impact of employee empowerment on the success of organizational change, the items of the questionnaire were rated using likert seven-points scale ranging between $1=$ Strongly Disagree and 7= Strongly Agree. (Bartlett et al, 2001). In addition to reliability, validity and multicollinearity test were conducted. Also simple and multiple regression test was conducted to test hypothesis.

\subsection{Reliability and Validity Test}

Reliability "is the proportion of variability in a measured score that is due to variability in the true score (rather than some kind of error)" (Roberts et al, 2006). In other words, reliability is the internal consistency of research instruments (Roberts et al, 2006).

Cronbachs ${ }^{\text {ee }}$ Alpha Coefficient is widely used for testing the reliability. The measure is considered to be reliable if the value of Cronbachs ${ }^{\text {ee }}$ Alpha Coefficient equals or exceeds $60 \%$

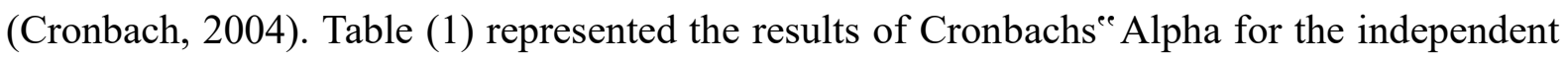
variable and dependent variable. 
Table (1): Reliability

\begin{tabular}{|l|l|}
\hline Variables & Cronbachs' Alpha Coefficient \\
\hline Talent management & .853 \\
\hline Leadership style & .866 \\
\hline Employee training & .871 \\
\hline Reward & .784 \\
\hline Employee Empowerment & .909 \\
\hline Success of organizational change & .752 \\
\hline Overall factors & .918 \\
\hline
\end{tabular}

\subsection{Hypothesis Testing Results}

To investigate the impact of employee empowerment on the success of organizational change according to (Talent management, leadership style, Employee training and Rewards) factors in privatized enterprises in Jordan multiple regression test was conducted. Furthermore, the level of significant ( $\alpha$ level) was chosen at 0.05 . However, the null hypothesis is accepted when probability value ( $\mathrm{p}$-value) $>0.05$ and is rejected at $\mathrm{P}<0.05$. To test if there is a multicollinearity problem or not, a Variance Inflation Factor (VIF) and Tolerance Values tests were carried out. VIF provides an indicator that measures how much the variance (the square of the estimate standard deviation) of an estimated regression coefficient is increased because of multicollinearity.VIF measures the impact of multicollinearity among the variables in a regression model. If VIF is more than 5 and the tolerance value is less than 0.2 that means that the factors don't have a multicollinearity problem. Table (2) shows multicollinearity test.

Table (2): Multicollinearity Test

\begin{tabular}{|l|l|l|}
\hline Factors & VIF & Tolerance \\
\hline Talent management & 1.335 & .749 \\
\hline Leadership style & 1.273 & .786 \\
\hline Employee training & 1.606 & .623 \\
\hline Reward & 1.276 & .788 \\
\hline
\end{tabular}


Table (3): Multiple Regression

\begin{tabular}{|c|c|c|c|c|c|c|c|}
\hline \multirow{2}{*}{ Variables } & \multicolumn{2}{|c|}{$\begin{array}{l}\text { Model } \\
\text { summary }\end{array}$} & \multicolumn{2}{|c|}{ ANOVA } & \multicolumn{3}{|c|}{ Coefficients } \\
\hline & $\mathrm{R}$ & $\mathrm{R}^{2}$ & $\mathrm{~F}$ & Sig. & $\beta$ & $\mathrm{T}$ & sig \\
\hline Talent management & \multirow{4}{*}{.617} & \multirow{4}{*}{.365} & \multirow{4}{*}{24.021} & \multirow{4}{*}{.000} & .335 & 4.631 & .000 \\
\hline Leadership style & & & & & .009 & .567 & .897 \\
\hline Employee training & & & & & .038 & .750 & .635 \\
\hline Rewards & & & & & .406 & 6.372 & .000 \\
\hline
\end{tabular}

Multiple regression analysis was conduct to test this hypothesis. The results from the above table can be illustrated as follows:

* The ANOVA table shows that $\mathrm{F}=24.021$ and $\mathrm{p}$-value $=0.000$ less than 0.05 (the level of significance). However, the null hypothesis is accepted at $\mathrm{P}>0.05$ and is rejected at $\mathrm{P}<0.05$. Hence, the null hypothesis was rejected. Thus, there is significant impact of employee empowerment dimensions (i.e. talent management, leadership style, employee training and rewards) on success of organizational change.

* As reflected by the model summary table, R value (.617) is the correlation value of employee empowerment dimensions (i.e. talent management, leadership style, employee training and rewards) on success of organizational change. While $\mathrm{R}^{2}$ (.365) of the explained variation in success of organizational change can be accounted for employee empowerment dimensions (i.e. talent management, leadership style, employee training and rewards).

According to the coefficients table, the $\mathrm{t}$ value is significant at 0.05 levels for employee empowerment dimensions (i.e. talent management and rewards). This indicates that there is a positive relationship between employee empowerment dimensions (i.e. talent management and rewards) and success of organizational change.

Reflected to $\beta$ value which gives an indication of how strongly a unit change in each independent variable affects the dependent variable. As shown one unit increase in employee empowerment dimensions (i.e. talent management and rewards) can significantly predict a (.335 and .406) increase in success of organizational change. 


\section{Discussion and Conclusions}

The aim of this study is to investigate the impact of employee empowerment on the success of organizational change, so the study has resorted to search within four factors representing employee empowerment (Talent Management, Leadership Style, Employee Training, Rewards ) through implement this study at Jordan Phosphate Mines Company, and Electricity Distribution Company, based on employees and leaders perspectives, which was used questionnaire method to collect data, it was distributed to (143) employee in both companies, and the response rate is $(99 \%)$ to submit to the appropriate statistical tests and to reach results.

There is a significant impact of employee empowerment on the success of organizational change, this result is corresponds to the findings of (Sharma and Sahoo,2014) study, when they pointed out that there are several factors to success of organizational change, such as empowerment.

Ramjee, (2007) pointed in his study on the role of training, leadership style, financial and non-financial rewards, and it's positive role to implement the employee empowerment process widely, participation in decision-making process, and performing their job well, which helps to increase commitment to work, job satisfaction and improving the organization's level of competition among organizations.

Based on a recommendation of Mathew,(2015) (as cited in Taleo Corporation, 2008), which focused that "Successful organizations know that exceptional business performance is driven by superior talent".

So, it is necessary to recognize the importance of Talent management in helping organization to growth and advancement of their strategies in order to stay in the environment, also the importance of the role of leaders and human resource professional to achieve the best results through help them and improve their capabilities and develop appropriate plans and how to attract and retain talent.

Hon, et al, (2011) emphasize that "anyone who creates a new idea to change should have the right to hold open discussions with others". This study also showed the importance of creativity and interest in new ideas that related about how to readiness to change and minimizing the resistance which inversely related to creativity and improving the performance of organizational employees.

According to the results, it can provide a set of recommendations, First: In the light of increased environmental requirements, the organization must to do more interest about the empowerment because of its positive impacts on human relations inside it through make way for employees to participate in the decision-making process, develop the employee skills, delegation of powers in consistent with their responsibilities manner and involve them to put and develop important strategy programs. Second: Because the leadership style is the less important factor, it's necessary for leaders to understand and awareness the importance of supporting individuals, and accepting their opinion, directing them by clarification of roles and responsibilities for each one. Also, follow an open-door policy by top management when 
they represent the change initiative to communicate employers voice and listening to their perspectives. Third: Based on the opinions that expressed respondents in the last part of questionnaire, linking the change initiative in organization with success, develop it and transcend the previous mistakes, not to make a profit and optimizing image of organization in front of the local community. Additionally, the executive departments should focusing on selection of staff based on merit, not by favoritism in order to gain positions, and interest of employee who gun-slinging with knowledge and skills, because it cannot achieve success in existence of enemies of knowledge

\section{References:}

Al-Haddad, S. and Kotnour, T. (2015), "Integrating the organizational change literature: a model for successful change", Journal of Organizational Change Management, Vol. 28 Iss 2 pp. $234-262$.

Ali, M. A, (2007), "Privatization: Islamic vision", Alghare journal for economic science and administration- Al-kofa university, Iraq, Vol 7, 84-100.

Al-Otaibi, S, (2004), "Ideas To Enhance Employee Empowerment in Arab Organizations", $5^{\text {th }}$ ArabConference On Administrative (Creativity And Innovation: The Role of Arabian Manager in Creativity and Excellence, The Arab Organization For Administrative Development-Egypt, pp. 90-117.

Alsharqatli, H.M, (2010), "The Effect of Privatization on the Financial performance of the Jordanian Companies and it Relation with Type, Size, and Development of the Company in the Market", Master Thesis- unpuplished, Middle East University, Jordan

Arneson, H. and Ekberg, K, (2006), "Measuring empowerment in working life: a review", Work, Vol. 26 No. 1, pp. 37-46.

Arnold JA, Arad S, Rhoades JA, and Drasgow F, (2000) "The empowering leadership questionnaire: The construction and validation of a new scale for measuring leader behaviors", Journal of Organizational Behavior21(3): 249-269.

Balogun, J. and Hope Hailey, V, (2004), "Exploring Strategic Change", 2nd ed., Prentice Hall, London.

Barlett, J. E., Kotrlik, J. W., \& Higgins, C. C. (2001) "Organizational research: Determining appropriate sample size in survey research", Information Technology, Learning, and Performance Journal, 19(1), 43.

Beer, M. and Nohria, N, (2000), "Cracking the code of change", Harvard Business Review, Vol. 78 No. 3, pp. 133-141.

Blanchard, K. H., J. P. Carlos, and W. A. Randolph. (1999), "The 3 keys to empowerment". San Francisco: Berrett-Koehler Publishers.

Bowen, D.E. and Lawler, E.E. (1992), "The empowerment of service workers: what, why, 
how and when", Sloan Management Review, Vol. 33, No. 3, pp. 31-9.

Brown, P. and Hesketh, A, (2004), "The Mismanagement of Talent: Employability and Jobs in the Knowledge Economy", Oxford University Press, Kinges Lynn.

Collings, D.G. and Mellahi, K, (2009), "Strategic talent management: a review and research agenda", Human Resource Management Review, Vol. 19 No. 4, pp. 304-13.

Cronbach, L. J., \& Shavelson, R. J, (2004), "My current thoughts on coefficient alpha and successor procedures". Educational and Psychological Measurement,64(3), 391-418.

Dainty, A.R., Bryman, A. and Price, A.D, (2002), "Empowerment within the UK construction sector", Leadership and Organization Development Journal, Vol. 23 No. 6, pp. 333-42.

Dessler, G, (2015), Human Resource Management, $14^{\text {th }}$,USA, Pearson Education.

Ettorre, Barbara, (1997), "The Empowerment Gap Hype Vs Reality", Br Focus, 26: 4.

Grover, V. (1999), "From business reengineering to business process change management: a longitudinal study of trends", IEEE Transactions on Engineering Management, Vol. 46 No. 1, pp. 36.

Hon, A. H. Y, Bloom, M, Crant, J. M, (2011), "Overcoming Resistance to Change and Enhancing Creative Performance", Journal of Management, Vol. 40 No. 3, March 2014 919-941.

Ingham, J. (2006), "Closing the talent management gap", Strategy HR Review,5(3), 20-23. Melcrum Publishing, (www.melcrum.com).

Jones, G. R. (2013), "Organizational Theory, Design and change", 7th Ed, USA: Pearson Prentice Hall.

Kirkman, B. L., and D. L. Shapiro, (1997), "The impact of cultural values on employee resistance to teams: Toward a model of globalized self-managing work team effectiveness", Academy of Management Review, 22:730-57.

Langbein, L.I. (2000), "Ownership, empowerment, and productivity: some empirical evidence on the causes and consequences of employee discretion", Journal of Policy Analysis and Management, Vol. 19 No. 3, pp. 427-49.

Lewin, K, (1951), "Field Theory in Social Science", Harper: USA, pp. 172-174.

Lewis, R.E. and Heckman, R.J, (2006), "Talent management: a critical review", Human Resource Management Review, Vol. 16 No. 2, pp. 139-54.

Mathew, A. (2015), "Talent Management Practices in Select Organizations in India", Global Business Review, 16(1) 137-150.

Melhem, Yahya S, (2009), " Empowerment As Administrative Contemporary Concept", Jordan: The Arab Organization For Administrative Development, Vol 1 Issue 2.

Ministry of Finance.2009. General Government Finance Bulletin , Amman, Vol.(10), No. 


\section{I Macrothink}

(12), pp: 113-124.

Nilsson,S. and Ellström,P, (2012), "Employability and talent management: challenges for HRD practices",European Journal of Training and Development, Vol. 36 Iss 1 pp. 26 - 45.

Pastor, J. (1996), "Empowerment: what it is and what it is not", Empowerment in Organizations, Vol.4 ,No. 2, pp. 5-7

Ramjee, M, (2007), "An Investigation Into The Impact Of Training and Leadership Programs On Employee Empowerment", Unpublished Master Thesis, NMMU Business School.

Randolph, W. A, (1995), "Navigating the journey to empowerment", Organizational Dynamic,23:19-32.

Randolph, W. A, (2000), "Re-thinking empowerment: Why is it so hard to achieve?" Organizational Dynamics, 29:94-107.

Raub,S. and Robert,C, (2010), "Differential effects of empowering leadership on in-role and extra-role employee behaviors: Exploring the role of psychological empowerment and power values",human relations, 63(11) 1743-1770.

Roberts, P., Priest, H., \& Traynor, M. (2006). "Reliability and validity in research", Nursing Standard, 20(44), 41-45.

Sharma, R . and Sahoo, C.K, (2014), "Education, Empowerment and Communication (EEC) as Drivers of Managing Change", Management and Labour Studies, 39(2) 174-186.

Spreitzer, G.M. (1995). "Psychological empowerment in the workplace: Dimensions, measurement, and validation. Academy of Management Journal, 38(5), 1442-1465.

Spreitzer, G. M, (1996), "Social structural characteristics of psychological Empowerment", Academy of Management Journal,39: 483-504.

Taleo Corporation. (2008)."Talent management in a down economy". Taleo Research White Paper, San Francisco.

Voegtlin,C. Boehm,S. and Bruch,H, (2015), "How to empower employees: using training to enhance work units ce collective empowerment", International Journal of Manpower, Vol. 36, Iss 3 pp. $354-373$.

Weiner, B.J, (2009), "A Theory of Organizational Readiness for Change", Implementing Science.

\section{Copyright Disclaimer}

Copyright for this article is retained by the author(s), with first publication rights granted to the journal.

This is an open-access article distributed under the terms and conditions of the Creative Commons Attribution license (http://creativecommons.org/licenses/by/3.0/). 